\title{
Introduction to International Law and the World Trade Organization
}

\author{
Rosanne Kennedy
}

Thanks to Kim and Hilary for organising this wonderful event and to the Cass family and Deborah's friends for being here.

I am honoured to have been invited to participate in this memorial symposium for my friend and colleague Deborah Cass. I teach in literary studies and gender studies in the College of Arts and Social Sciences at The Australian National University (ANU).

I first met Deborah in 1992 when we were both newly arrived at ANU, and we quickly discovered that we had a shared interest in gender and feminist legal theory. I was excited to meet this vibrant, engaging and energetic new colleague. She invited me to speak to her legal theory class. I envied her sense of style, and although I don't remember her doing so, she probably wanted to give me fashion advice! The next thing I knew she had won the Caltex award and was off to Harvard. When we met again a couple of years later, it was at the University Child Care Centre across the street from here, so it's particularly nice to be meeting in this location today - which used to be the staff club before it had its reincarnation as the Crawford School. Hannah and my son Benjamin became good friends, and not long after Deborah had Rosa and I had Isobel, and they too became friends. Many of my and Deborah's subsequent conversations took place in the hectic circumstances of the playground, birthday parties and picnics, although I do remember a lively night out at a Canberra 
restaurant to celebrate Deborah's 40th birthday. Our conversations dealt with the issues of everyday life: mothering, parenting, feminism, being a woman in the academy, among other intellectual topics.

When the family moved to London, we stayed in touch. I visited them in their London house and went walking with Deborah in the local park. She seemed to love the London life. One of my fondest memories of Deborah was when the family visited us for Christmas at the beach (Bermagui). The kids made a Christmas tree out of driftwood and decorations out of tinfoil and Hannah received a surf board! I have lovely pictures and funny stories from those years, but I'll spare Hannah and Rosa the embarrassment. One thing that I remember with considerable nostalgia was the frequent conversations I had with Deborah and Gerry about literature. Somehow, despite the demands of careers, families and international travel, we found time to read. We often discussed novels and writers, and traded novels. That, as well as her own creative writing, was such an important part of Deborah's life.

Speaking of books, my task today is to chair a session on Deborah Cass's book, The Constitutionalization of the World Trade Organization: Legitimacy, Democracy, and Community in the International Trading System, which was published by Oxford University Press in 2005. It won the Certificate of Merit from the American Society for International Law. The book has been praised by eminent scholars as 'that rare thing: An account which is sophisticated at both a theoretical and a doctrinal level' and as setting 'a benchmark for all future writing on this theme'. Described as 'build[ing] important bridges between political philosophy and international law' this book is central to today's discussion of how Deborah Cass's scholarship 'traverses divides'. 
This text is taken from Traversing the Divide: Honouring Deborah Cass's Contributions to Public and International Law, edited by Kim Rubenstein, published 2021 by ANU Press, The Australian National University,

Canberra, Australia.

doi.org/10.22459/TD.2021.06 